\title{
Serangan Asma Berat pada Asma Episodik Sering
}

\author{
Ariz Pribadi, Darmawan BS
}

Kasus asma serangan berat dengan episodik sering terjadi pada seorang anak berusia 14 bulan. Penanganan pertama untuk mengatasi eksaserbasi adalah pemberian berulang $\beta_{2}$-agonist secara inhalasi, glukokortikoid sistemik, dan oksigen. Apabila pasien tidak menunjukkan respons terhadap pengobatan awal dan terlihat adanya perburukan klinis sehingga pasien harus dirawat di ruang perawatan intensif atas indikasi ancaman henti napas ( $\mathrm{Pa} \mathrm{C02}>45 \mathrm{~mm} \mathrm{Hg}$ ). Dengan pemberian obat kombinasi anti kolinergik, multixantin intravena, dan glukokortikoid sistemik terlihat perbaikan dalam waktu 24 jam. Serangan eksaserbasi asma yang berat dapat mengancam hidup dan merupakan keadaan darurat yang memerlukan penanganan segera.

Kata kunci: asma, eksaserbasi, $\beta_{2}$-agonis, inhalasi

$\mathscr{A}$ sma merupakan penyakit inflamasi respiratorik kronik, masih menjadi masalah kesehatan yang perlu mendapatkan perhatian khususnya pada anak. Dalam dua puluh tahun terakhir ini angka kejadian asma cenderung meningkat baik di negara maju maupun negara berkembang. Prevalensi asma di dunia diperkirakan 7,2\% (6\% pada dewasa dan $10 \%$ pada anak). Prevalensi tersebut sangat bervariasi, baik antar negara, bahkan antar daerah di suatu negara. ${ }^{1,2}$

Dalam tatalaksana serangan asma pada umumnya dan penanganan serangan asma berat khususnya, masih ada beberapa hal yang masih diperdebatkan. Pada dasarnya tujuan tatalaksana serangan asma untuk melebarkan jalan napas secepat mungkin, mengurangi hipoksemia, dan mengembalikan fungsi paru ke keadaan normal secepatnya, serta mencegah kekambuhan. ${ }^{1}$

\footnotetext{
Alamat korespondensi:

Dr. Darmawan BS, Sp.A(K)

Divisi Pulmonologi Departemen Ilmu Kesehatan Anak FKUI-RSCM Jl. Salemba no. 6, Jakarta 10430.

Telepon: 021-3100669. Fax.021-390 7743
}

Dr. Ariz Pribadi: PPDS Ilmu Kesehatan Anak FKUI, Jakarta
Laporan kasus ini bertujuan untuk mendiskusikan tata laksana asma serangan berat pada anak.

\section{Kasus}

Seorang anak laki-laki usia 14 bulan dirujuk dengan status asmatikus dan respiratory failure untuk dirawat di Unit Perawatan Intensif (UPI) Bagian Anak RSUPN dr. Cipto Mangunkusumo (RSCM). Aloanamnesis dari ibu pasien diketahui bahwa 5 hari sebelum dirawat di RSCM, pasien batuk dan pilek, tanpa demam; saat itu ibu pasien jugasedang menderita batuk. Tidak ada keluhan buang air besar maupun buang air kecil. Asupan oral masih baik. Pasien kemudian dibawa berobat ke dokter Spesialis Anak dan mendapat pengobatan, namun tidak ada perbaikan. Satu hari sebelum masuk rumah sakit batuk semakin sering, sehingga asupan oral kurang. Batuk terutama pada malam hari sehingga pasien sering terbangun. Sepuluh jam sebelum masuk rumah sakit, batuk makin sering disertai dengan dahak yang bertambah banyak. Pasien kemudian dibawa ke fisioterapis dan mendapat terapi inhalasi, namun batuk tidak berhenti dan pasien bertambah rewel. Enam jam sebelum masuk rumah sakit pasien tampak sesak dan napas berbunyi ngik-ngik. Pasien kemudian dibawa ke Rumah Sakit M 
dan diberi cairan infus, steroid intravena, serta inhalasi dua kali. Saat itu hasil analisis gas darah menunjukkan $\mathrm{pH}$ 7,281, $\mathrm{pCO}_{2}$ 49,9 mmHg, $\mathrm{pO}_{2}$ 71,9 mmHg, $\mathrm{HCO}_{3}-23,1 \mathrm{meq} / \mathrm{L}$, base excess $-3,8 \mathrm{meq} / \mathrm{L}$, saturasi $\mathrm{O}_{2}$ 92,9\%, sehingga pasien kemudian dirujuk ke RS Dr. Cipto Mangunkusumo (RSCM).

Pasien sering batuk, pilek, dan sesak napas sejak usia 4 bulan. Keluhan ini timbul terutama jika di dalam rumah ada yang menderita batuk dan pilek. Batuk berkurang apabila pasien mendapatkan inhalasi. Saat usia 7 bulan, keluhan sesak timbul kembali disertai batuk, pilek dan demam. Saat itu pasien mendapat terapi inhalasi tujuh kali (berobat jalan). Sejak usia 9 bulan serangan sesak napas timbul setiap bulan dan setelah mendapat terapi inhalasi, keluhan membaik. Dijumpai riwayat atopi pada nenek (dari ibu) pasien berupa asma, sedangkan ibu pasien menderita alergi terhadap makanan laut. Tidak ada riwayat atopi dari pihak keluarga ayah dan tidak ada yang merokok di dalam rumah. Kehamilan ibu normal. Selama hamil ibu kontrol teratur ke Spesialis Kebidanan, tidak pernah menderita sakit, minum obat-obatan, jamu, alkohol maupun merokok kecuali minum vitamin yang diberikan oleh dokter. Pasien merupakan anak pertama, lahir dengan operasi kaisar atas indikasi lilitan tali pusat, langsung menangis, cukup bulan, berat lahir 3720 gram dan panjang lahir $48,5 \mathrm{~cm}$. Pasien sudah mendapatkan imunisasi dasar lengkap. Pemeriksaan fisis saat masuk RSCM didapatkan kesadaran pasien kompos mentis, tampak sesak, nafas cuping hidung, tidak pucat maupun sianosis. Laju nadi 136 kali per menit, teratur, isi cukup, laju napas 60 kali per menit, suhu (aksila) $37,8^{\circ} \mathrm{C}$. Berat badan $11,5 \mathrm{~kg}$ ( $\left.\mathrm{P}_{75} \mathrm{NCHS}\right)$, panjang badan $80 \mathrm{~cm}$ ( $\left.\mathrm{P}_{50} \mathrm{NCHS}\right)$, lingkar kepala 46 $\mathrm{cm}$ (normal). Ditemukan sekret jernih pada hidung.

Pada pemeriksaan toraks tampak expiratory effort, retraksi suprasternal dan epigastrium. Suara napas vesikular, terdengar ronki basah kasar dengan mengi. Bunyi jantung normal. Perut teraba lemas, turgor kulit cukup, bising usus terdengar normal, hati dan limpa tidak teraba. Akral hangat, perfusi perifer cukup, refleks fisiologis normal, tidak dijumpai refleks patologis.

Pemeriksaan darah tepi saat masuk RSCM didapatkan hemoglobin $11,9 \mathrm{~g} / \mathrm{dl}$, hematokrit 37 vol.\%, leukosit $7.000 / \mathrm{mL}$, trombosit $278.000 / \mathrm{mL}$, hitung jenis basofil $0 \%$, eosinofil $0 \%$, neutrofil batang $3 \%$, neutrofil segmen $79 \%$, limfosit $17 \%$, monosit $1 \%$. Analisis gas darah $\mathrm{pH} 7,263, \mathrm{pCO}_{2} 39 \mathrm{mmHg}, \mathrm{pO}_{2} 85,3 \mathrm{mmHg}$ $\left(\mathrm{O}_{2} 4\right.$ liter/menit, sungkup), $\mathrm{HCO}_{3}^{-1} 17,9 \mathrm{meq} / \mathrm{L}$, base excess $-6,3$ meq/L, saturasi $\mathrm{O}_{2} 94,9 \%$. Foto toraks kesan hiperaerasi sesuai dengan asma bronkial, tidak tampak atelektasis. (Gambar 1)

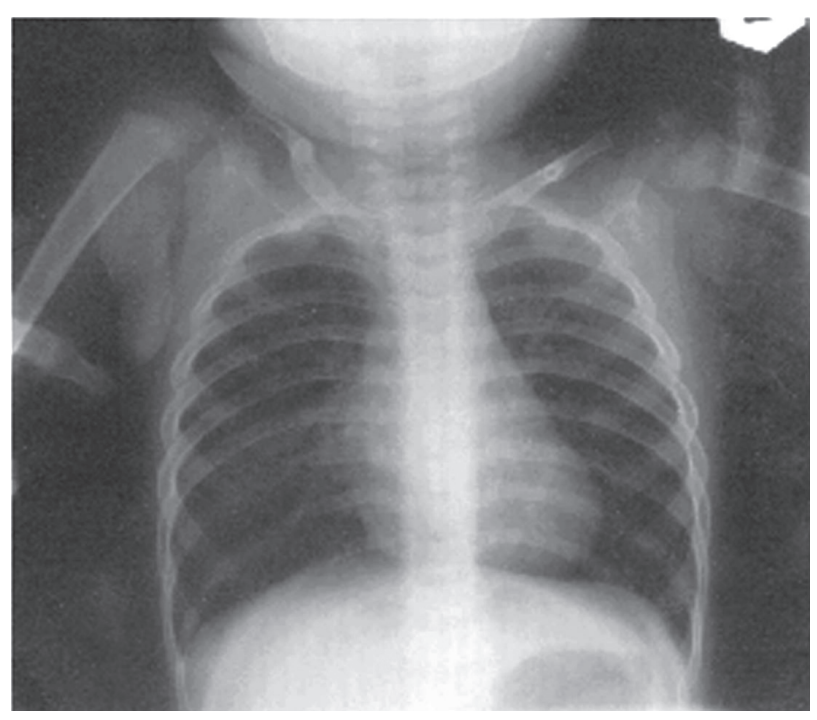

Gambar 1. Foto toraks menunjukkan adanya hiperaerasi, tidak tampak atelektasis

Saat itu ditegakkan diagnosis asma episodik sering serangan berat. Pasien dirawat di Unit Perawatan Intensif Departemen Ilmu Kesehatan Anak RSCM dan diberi oksigen 4 liter/menit melalui sungkup dan cairan intravena (dekstrosa 5\%: Nacl 0,9\% 3:1) KaEn $1 \mathrm{~B}^{\circledR}+$ $\mathrm{KCl} 10 \mathrm{meq} / 500 \mathrm{~mL}, 1200 \mathrm{ml}$ perhari. Terapi inhalasi salbutamol dan ipatropium bromida setiap 2 jam. Aminofilin inisial $72 \mathrm{mg}$ dalam larutan dekstrosa 5\% 20 ml dalam waktu 20 menit, kemudian dilanjutkan dengan dosis rumatan $12 \mathrm{mg} / \mathrm{jam}$. Deksametason diberikan 3x2 mg intravena. Hasil analisis gas darah 10 jam kemudian menunjukkan $\mathrm{pH}$ 7,316, $\mathrm{pCO}_{2} 37,9$ mmHg, $\mathrm{pO}_{2}$ 126,4 $\mathrm{mmHg}\left(\mathrm{O}_{2} 4\right.$ liter/menit, sungkup $), \mathrm{HCO}_{3}^{-2} 25,5$ meq/ $\mathrm{L}$, base excess $-2,5 \mathrm{meq} / \mathrm{L}$, saturasi $\mathrm{O}_{2} 98,1 \%$. Pada perawatan hari ke- 2 , sesak mulai berkurang dengan laju napas $48-54$ kali per menit, suhu (aksila) $36,5-37,2^{\circ} \mathrm{C}$, retraksi suprasternal dan epigastrium berkurang. Pasien dicoba untuk minum peroral, toleransi baik; $\mathrm{O}_{2}$ diturunkan menjadi 2 liter/menit (nasal), dan inhalasi setiap 4 jam.

Pada perawatan hari ke-3, keadaan umum pasien semakin baik, tidak tampak sesak. Pasien dipindahkan ke ruang rawat biasa. Jalur intravena dihentikan, terapi inhalasi masih diberikan dua kali sehari, obat peroral yaitu salbutamol, ambroksol dan teofilin empat kali 
sehari. Pasien dipulangkan pada hari ke-4 perawatan dengan anjuran untuk berobat kembali dua minggu kemudian.

\section{Diskusi}

Program Global Initiative for Asthma (GINA) yang dibentuk pada tahun 1993 atas kerjasama antara National Heart and Blood Institute (NHLBI) dan WHO, menggambarkan konsep inflamasi sebagai dasar mekanisme terjadinya asma. Berdasarkan revisi terakhir tahun 2002 asma didefinisikan sebagai gangguan inflamasi kronik saluran napas yang melibatkan peran banyak sel, khususnya sel mast, eosinofil, dan limfosit $T$. Inflamasi kronik ini akan menyebabkan peningkatan hiperreaktivitas jalan napas yang memicu terjadinya episod mengi berulang, sesak napas, rasa dada tertekan dan batuk terutama pada malam atau dini hari. Gejala ini biasanya berhubungan dengan penyempitan jalan napas yang luas namun bervariasi; dapat bersifat reversibel baik secara spontan maupun dengan pengobatan. ${ }^{1} \mathrm{Di}$ Indonesia pada tahun 1994 Unit Kerja Koordinasi Pulmonologi Ikatan Dokter Anak Indonesia telah mengeluarkan Konsensus Nasional Asma Anak (KNAA) yang direvisi ulang pada bulan Desember 1998. Secara garis besar KNAA terdiri dari dua bagian, yaitu tata laksana jangka panjang dan penanganan serangan asma. Batasan asma yang digunakan adalah mengi berulang dan/atau batuk persisten; keadaan asma adalah penyebab yang paling mungkin, setelah sebab lain yang lebih jarang disingkirkan. ${ }^{3}$

Gejala mengi berulang dan/atau batuk kronik berulang merupakan titik awal untuk menuju diagnosis. Yang perlu dipertimbangkan untuk kemungkinan diagnosis asma adalah anak, apabila anak hanya menunjukkan batuk sebagai satu-satunya gejala, dan pada saat diperiksa tanda-tanda mengi, sesak dan lain-lain tidak ditemukan. Kelompok yang patut diduga asma adalah anak-anak yang menunjukkan batuk dan/atau mengi yang timbul secara episodik, cenderung pada malam atau dini hari, musiman, setelah aktivitas fisik, serta adanya riwayat asma dan atopi pada pasien atau keluarganya. ${ }^{3}$ Derajat penyakit asma ditentukan berdasarkan penilaian gambaran klinis, jumlah pemakaian $b_{2}$-agonis untuk mengatasi gejala, dan uji fungsi paru pada penilaian awal. ${ }^{1,4}$ GINA 2002 membagi derajat penyakit asma menjadi empat tipe yaitu intermiten, persisten ringan, persisten sedang, dan persisten berat. ' Sedangkan KNAA membagi asma anak menjadi tiga derajat penyakit yaitu asma episodik jarang (asma ringan) dengan frekuensi serangan $<1$ kali/bulan, asma episodik sering (asma sedang) dengan frekuensi serangan $>1 \mathrm{kali} / \mathrm{bulan}$, dan asma persisten (asma berat) dengan frekuensi serangan yang sering dan lama serangan hampir sepanjang tahun. ${ }^{3}$

Pada kasus ini, pasien telah mengalami batuk kronik berulang disertai sesak napas sejak usia 4 bulan. Keluhan ini makin sering timbul (setiap bulan) sejak usia 9 bulan. Riwayat atopi ditemukan pada nenek dan ibu pasien.

Eksaserbasi (serangan asma) adalah episode perburukan yang progresif dari gejala sesak napas, batuk, mengi, rasa dada tertekan, atau berbagai kombinasi dari gejala tersebut. ${ }^{1}$ Pada uji faal paru dapat dijumpai penurunan $\mathrm{PEF} / \mathrm{FEV} 1 ;{ }^{1,5}$ pengukuran ini merupakan indikator yang lebih dipercaya dibandingkan dengan derajat gejala. Derajat gejala lebih berat pada awal terjadinya eksaserbasi karena memburuknya gejala serangan asma biasanya mendahului penurunan PEF. ${ }^{6}$ Derajat serangan asma bervariasi mulai dari serangan ringan hingga yang mengancam jiwa, dan perburukan dapat terjadi dalam beberapa menit, jam atau hari. Serangan akut biasanya terjadi akibat terpajan faktor pencetus, tersering adalah infeksi virus atau alergen. Serangan perburukan yang terjadi secara bertahap mencerminkan kegagalan pengelolaan jangka panjang dari penyakit asma. Penilaian derajat serangan asma dapat dilihat pada Tabel $1{ }^{1}$

Pada kasus ini, kemungkinan faktor pencetus timbulnya serangan asma adalah infeksi virus. Keadaan pasien sesuai dengan serangan berat yang terjadi pada pasien asma episodik sering. Uji faal paru tidak dilakukan mengingat usia pasien yang belum mampu laksana.

Kejadian utama pada serangan asma akut adalah obstruksi jalan napas secara luas yang merupakan kombinasi dari spasme otot polos bronkus, edem mukosa karena inflamasi saluran napas, dan sumbatan mukus. Sumbatan yang terjadi tidak seragam/merata di seluruh paru. Atelektasis segmental atau subsegmental dapat terjadi. Sumbatan jalan napas menyebabkan peningkatan tahanan jalan napas, terperangkapnya udara, dan distensi paru berlebihan (hiperinflasi). Perubahan tahanan jalan napas yang tidak merata di seluruh jaringan bronkus, menyebabkan tidak padu padannya ventilasi dengan perfusi. ${ }^{7}$ Hiperinflasi paru menyebabkan penurunan compliance paru, sehingga terjadi peningkatan kerja napas. Peningkatan tekanan intrapulmonal yang diperlukan untuk ekspirasi melalui saluran napas yang 
Tabel 1. Derajat serangan asma ${ }^{1}$

\begin{tabular}{|c|c|c|c|c|}
\hline & Ringan & Sedang & Berat & Ancaman henti napas \\
\hline \multirow[t]{2}{*}{ Sesak napas } & $\begin{array}{l}\text { Berjalan } \\
\text { Bayi: menangis keras }\end{array}$ & $\begin{array}{l}\text { Bicara } \\
\text { Bayi: tangis melemah } \\
\text { dan memendek, sulit } \\
\text { menetek/minum }\end{array}$ & $\begin{array}{l}\text { Saat istirahat } \\
\text { Bayi: tidak mau menetek/ } \\
\text { minum }\end{array}$ & \\
\hline & Dapat berbaring & $\begin{array}{l}\text { Lebih enak } \\
\text { posisi duduk }\end{array}$ & $\begin{array}{l}\text { Duduk } \\
\text { membungkuk } \\
\text { ke depan }\end{array}$ & \\
\hline Berbicara & $\begin{array}{l}\text { Menggunakan } \\
\text { kalimat }\end{array}$ & $\begin{array}{l}\text { Penggalan } \\
\text { kalimat }\end{array}$ & Kata-kata & \\
\hline Kesadaran & $\begin{array}{l}\text { Mungkin gelisah } \\
\text { (tidak tenang) }\end{array}$ & $\begin{array}{l}\text { Gelisah } \\
\text { (tidak tenang) }\end{array}$ & $\begin{array}{l}\text { Gelisah } \\
\text { (tidak tenang) }\end{array}$ & $\begin{array}{l}\text { Mengantuk atau } \\
\text { bingung }\end{array}$ \\
\hline Frekuensi napas & Meningkat & Meningkat & $\begin{array}{l}\text { Sering } \\
>30 \mathrm{kali} / \mathrm{menit}\end{array}$ & \\
\hline
\end{tabular}

Frekuensi napas normal anak (dalam keadaan bangun):

$\begin{array}{ll}\text { Usia } & \text { frekuensi normal } \\ <2 \text { bulan } & <60 \mathrm{kali} / \mathrm{menit} \\ 2-12 \text { bulan } & <50 \mathrm{kali} / \mathrm{menit} \\ 1-5 \text { tahun } & <40 \mathrm{kali} / \text { menit } \\ 6-8 \text { tahun } & <30 \mathrm{kali} / \text { menit }\end{array}$

Penggunaan otot-otot pernapasan tambahan Biasanya tidak dan retraksi dijumpai Biasanya dijumpai Biasanya dijumpai

Pergerakan torakoabdominal yang paradoks suprasternal

\begin{tabular}{|c|c|c|c|c|}
\hline Mengi & $\begin{array}{l}\text { Sedang, sering } \\
\text { hanya pada } \\
\text { akhir ekspirasi }\end{array}$ & Keras & Keras & Menghilang \\
\hline Frekuensi nadi & $<100 \mathrm{kali} / \mathrm{menit}$ & $100-120 \mathrm{kali} / \mathrm{menit}$ & $>120 \mathrm{kali} / \mathrm{menit}$ & Bradikardi \\
\hline \multicolumn{5}{|c|}{$\begin{array}{cc}\text { Usia } & \text { frekuensi norm } \\
\text { Bayi }(2-12 \text { bulan }) & <160 \mathrm{kali} / \mathrm{men} \\
\text { Prasekolah }(1-2 \text { tahun }) & <120 \mathrm{kali} / \mathrm{men} \\
\text { Sekolah }(2-8 \text { tahun }) & <110 \mathrm{kali} / \mathrm{mer}\end{array}$} \\
\hline Pulsus paradoksus & $\begin{array}{l}\text { Tidak ada } \\
<10 \mathrm{mmHg}\end{array}$ & $\begin{array}{l}\text { Mungkin ada } \\
10-25 \mathrm{mmHg}\end{array}$ & $\begin{array}{l}\text { Sering ada } \\
>25 \mathrm{mmHg} \text { (dewasa) } \\
20-40 \mathrm{mmHg} \\
\text { (anak) }\end{array}$ & $\begin{array}{l}\text { Menghilang, } \\
\text { menandakan adanya } \\
\text { kelemahan otot } \\
\text { pernapasan }\end{array}$ \\
\hline $\begin{array}{l}\text { PEF setelah } \\
\text { bronkodilator inisial }\end{array}$ & $>80 \%$ & $60-80 \%$ & $<60 \%$ & \\
\hline $\begin{array}{l}\mathrm{PaO}_{2} \\
\text { Dan/atau } \mathrm{PaCO}_{2}\end{array}$ & $\begin{array}{l}\text { Normal, biasanya tidak } \\
\text { perlu diperiksa } \\
<45 \mathrm{mmHg}\end{array}$ & $<45 \mathrm{mmHg}$ & $\begin{array}{l}<60 \mathrm{mmHg} \\
\text { Mungkin sianosis } \\
>45 \mathrm{mmHg} \\
\text { Mungkin gagal napas }\end{array}$ & \\
\hline Sat $\mathrm{O}_{2}$ & $>95 \%$ & $91-95 \%$ & $<90 \%$ & \\
\hline
\end{tabular}

Hiperkapni (hipoventilasi) lebih sering terjadi pada anak kecil dibandingkan dengan remaja atau dewasa

menyempit, dapat makin mempersempit atau menyebabkan penutupan dini saluran napas, sehingga meningkatkan risiko terjadinya pneumotoraks.
Peningkatan tekanan intratorakal mungkin mempengaruhi arus balik vena dan mengurangi curah jantung yang bermanifestasi sebagai pulsus paradoksus. ${ }^{8}$ 
Ventilasi perfusi yang tidak padu padan, hipoventilasi alveolar, dan peningkatan kerja napas menyebabkan perubahan dalam gas darah. Pada awal serangan, untuk mengkompensasi keadaan hipoksia terjadi hiperventilasi sehingga kadar $\mathrm{paCO}_{2}$ akan turun serta dijumpai alkalosis respiratorik. Selanjutnya pada obstruksi jalan napas yang berat, akan terjadi kelelahan otot napas dan hipoventilasi alveolar yang berakibat terjadinya hiperkapnia dan asidosis respiratorik. Karena itu jika dijumpai kadar $\mathrm{paCO}_{2}$ yang cenderung naik walau nilainya masih dalam rentang normal, harus diwaspadai sebagai tanda kelelahan dan ancaman gagal napas. Selain itu dapat terjadi pula asidosis metabolik akibat hipoksia jaringan dan produksi laktat oleh otot napas. ${ }^{8}$ Hipoksia dan asidosis dapat menyebabkan vasokonstriksi pulmonal, namun jarang menyebabkan cor pulmonale. Hipoksia dan vasokonstriksi dapat merusak sel alveoli sehingga produksi surfaktan berkurang atau tidak ada, sehingga meningkatkan risiko terjadinya atelektasis. ${ }^{8}$

Tujuan tata laksana serangan asma adalah untuk meredakan penyempitan jalan napas secepat mungkin, mengurangi hipoksemia, mengembalikan fungsi paru secepatnya, dan rencana mencegah kekambuhan. ${ }^{1}$ (lihat Bagan 1)

Penanganan awal terhadap pasien dalam serangan



Bagan 1. Alur tata laksana serangan asma ${ }^{1,3}$ 
asma adalah pemberian $\mathrm{b}_{2}$-agonis secara nebulisasi yang dapat diulang dua kali dengan selang waktu 20 menit. Pada pemberian ketiga dapat ditambahkan obat antikolinergik (Bagan 1). ${ }^{8}$ Penanganan awal ini sekaligus dapat berfungsi sebagai penapis untuk penentuan derajat serangan, karena penilaian derajat secara klinis tidak selalu dapat dilakukan dengan cepat dan tepat. Pada serangan asma berat, KNAA menganjurkan pemberian $\mathrm{b}_{2}$-agonis bersama-sama dengan ipatropium bromida. ${ }^{3}$ Pemberian dengan cara nebuliser untuk usia 18 bulan - 4 tahun dianjurkan menggunakan mouthpiece daripada masker muka untuk menghindari deposisi obat di muka dan mata. ${ }^{9}$ Obat-obat $\beta_{2}$-agonis yang sering dipakai dalam tata laksana serangan asma berat adalah salbutamol, terbutalin, dan fenoterol. ${ }^{1}$ Dosis inhalasi salbutamol 0,1$0,15 \mathrm{mg} / \mathrm{kg}$ berat badan/kali, maksimal $5 \mathrm{mg} /$ dosis, dapat diberikan 3 kali dengan interval 20 menit. Dosis inhalasi terbutalin 2,5 $\mathrm{mg}$ ( 1 respules)/kali. Dosis inhalasi fenoterol $0,1 \mathrm{mg} / \mathrm{kg}$ berat badan $/ \mathrm{kali} .{ }^{10}$ Pemberian $\beta_{2}$-agonis secara intravena secara teori berguna pada serangan asma berat yang tidak memberikan respon dengan pemberian secara inhalasi. Tetapi pada beberapa penelitian tidak terdapat perbedaan yang signifikan pada efek bronkodilatasi dari pasien-pasien yang diberi $\beta_{2}$-agonis secara intravena maupun inhalasi. ${ }^{11}$ Kombinasi antara inhalasi $\beta_{2}$-agonis dan antikolinergik (ipatropium bromida) akan memberikan efek bronkodilatasi yang lebih baik. ${ }^{1,8,12}$ Kombinasi ini sebaiknya diberikan terlebih dulu sebelum diberikan metil-xantin. ${ }^{1}$ Dosis ipatropium bromida yang dianjurkan adalah 8-20 tetes (usia $>6$ tahun) dan 4-10 tetes (usia $\leq 6$ tahun) larutan NaCL 0,025\%. ${ }^{3}$ Pada kasus ini, pasien langsung diberikan kombinasi inhalasi $\beta_{2}$ agonis (salbutamol) dan ipatropium bromida sejak di RS $\mathrm{M}$, tetapi tidak menunjukkan perbaikan klinis. Efek bronkodilatasi golongan metil-xantin setara dengan inhalasi $b_{2}$-agonis, tetapi karena efek samping yang lebih banyak dan batas keamanan yang sempit maka golongan metil-xantin hanya dianjurkan jika pemberian kombinasi inhalasi $\mathrm{b}_{2}$-agonis dan ipatropium bromida tidak memberikan respons. ${ }^{1,13,14}$ Metil-xantin (aminofilin) diberikan secara intravena dengan dosis awal $4-6 \mathrm{mg} / \mathrm{kg}$ berat badan dilarutkan dalam dekstrosa $5 \%$ atau garam fisiologis sebanyak $20 \mathrm{ml}$ dan diberikan dalam 20-30 menit. Aminofilin rumatan diberikan dengan dosis 0,5$1 \mathrm{mg} / \mathrm{kg}$ berat badan/jam. ${ }^{3,15}$ Bila pasien telah mendapat aminofilin sebelumnya (kurang dari 4 jam), maka dosis diberikan setengahnya. Pada kasus ini, pemberian aminofilin intravena diberikan setelah pemberian kombinasi inhalasi $\mathrm{b}_{2}$-agonis dan ipatropium bromida tidak memberikan respons. Pemberian kortikosteroid sistemik akan mempercepat perbaikan dari serangan asma. ${ }^{1}$ Kortikosteroid sistemik diberikan jika pada terapi awal serangan (dengan menggunakan inhalasi $\mathrm{b}_{2}$-agonis) gagal mencapai perbaikan, tetap terjadi serangan walaupun pasien telah menggunakan kortikosteroid oral, atau pada serangan asma sebelumnya pasien telah menggunakan kortikosteroid oral. ${ }^{1}$ Kortikosteroid dapat diberikan secara intravena. Metil prednisolon merupakan pilihan utama, dosis yang dianjurkan $1 \mathrm{mg} / \mathrm{kg}$ berat badan tiap 4-6 jam. Hidrokortison $4 \mathrm{mg} / \mathrm{kg}$ berat badan tiap 4-6 jam. Deksametason $0,5-1 \mathrm{mg} / \mathrm{kg}$ berat badan bolus dilanjutkan dengan $1 \mathrm{mg} / \mathrm{kg}$ berat badan/hari tiap 6-8 jam. ${ }^{16}$ Pada kasus ini, pemberian kortikosteroid sistemik (deksametason) telah diberikan sejak di RS $M$, tetapi tidak menunjukkan perbaikan klinis. Kortikosteroid tetap diberikan hingga perbaikan klinis pasien pada hari ke-3.

Pasien yang datang dengan serangan asma berat yang disertai dehidrasi dan asidosis metabolik, mungkin akan mengalami takifilaksis atau refrakter, yaitu respons yang kurang baik terhadap nebulisasi $\beta_{2}$ agonis. Pasien seperti ini cukup dinebulisasi sekali saja kemudian secepatnya dirawat untuk mendapatkan obat intravena, selain diatasi masalah dehidrasi dan asidosisnya. ${ }^{3}$ Dehidrasi yang terjadi dapat disebabkan baik oleh karena asupan cairan yang tidak adekuat maupun peningkatan insensible water lost karena takipne. Cairan yang diberikan untuk koreksi dehidrasi biasanya cukup 1-1,5 kali kebutuhan rumatan. ${ }^{17}$ Pada kasus ini untuk mengatasi dehidrasi yang timbul akibat asupan cairan yang tidak adekuat maupun peningkatan insensible water lost karena takipne diberikan cairan sesuai dengan kebutuhan rumatan. Indikasi perawatan di Unit Perawatan Intensif pada kasus ini adalah perburukan asma yang cepat dan tidak ada respons sama sekali terhadap tata laksana awal, disertai dengan ancaman henti napas $\left(\mathrm{paCO}_{2}>45 \mathrm{mmHg}\right.$ saat analisis gas darah di Rumah Sakit M).

Indikasi rawat di ruang rawat intensif 1,3

1. Tidak ada respons sama sekali terhadap tata laksana awal dan/atau perburukan asma yang cepat.

2. Adanya kegelisahan, nyeri kepala, dan tanda lain ancaman henti napas, atau hilangnya kesadaran.

3. Tidak ada perbaikan dengan pengobatan baku di ruang rawat inap.

4. Ancaman henti napas yang ditandai oleh hipoksemia 
yang menetap walaupun sudah diberi oksigen (kadar $\mathrm{paO}_{2}<60 \mathrm{mmHg}$ dan/atau $\mathrm{paCO}_{2}>45 \mathrm{mmHg}$, walaupun begitu gagal napas dapat terjadi pada kadar $\mathrm{paCO}_{2}$ yang lebih tinggi atau lebih rendah)

Indikasi pemasangan ventilasi mekanik pada serangan asma berat ${ }^{17}$

1. Pulsus paradoksus yang cepat meningkat.

2. Penurunan pulsus paradoksus pada pasien yang kelelahan.

3. Status mental yang memburuk (letargi atau agitasi).

4. Henti jantung.

5. Henti napas.

6. Asidosis laktat yang sulit dikoreksi.

7. Hipoksemia $\left(\mathrm{paO}_{2}<60 \mathrm{mmHg}\right)$ yang tidak membaik dengan pemberian oksigen $100 \%$, $\mathrm{paCO}_{2}>60 \mathrm{mmHg}$ dan meningkat $>5 \mathrm{mmHg} /$ jam.

\section{Daftar Pustaka}

1. Global Initiative for Asthma. Global strategy for asthma management and prevention. National Institute of Health. National Heart, Lung, and Blood Institute 2002 (revisi). Diperbaharui dari: NHLBI/WHO workshop report: global strategy for asthma management and prevention issued January 1995; NIH publ. no.02-3659.

2. Kartasasmita CB. Epidemiologi asma anak. Disampaikan pada Indonesian Pediatric Respiratory Meeting I/2003: Focus on Asthma, Jakarta 8-10 Agustus, 2003.

3. Unit Kerja Koordinasi Pulmonologi, Ikatan Dokter Anak Indonesia. Konsensus Nasional Asma Anak. Sari Pediatri 2000; 2:50-66.

4. Cockroft DW, Swystun VA. Asthma control versus asthma severity. J Allergy Clin Immunol 1996; 98:1016-8.

5. FitzGerald JM, Grunfeld A. Status asthmaticus. Dalam: Lichtenstein LM, Fauci AS, penyunting. Current therapy in allergy, immunology, and rheumatology. Edisi ke-5. St. Louis, MO: Mosby; 1996. h. 63-7.
6. Turner MO, Taylor D, Bennet R, FitzGerald JM. A randomized trial comparing peak expiratory flow and symptom self-management plans for patients with asthma attending a primary care clinic. Am J Respir Crit Care Med 1998; 157:540-6.

7. Warner JO, Naspitz CK, Cropp GJA. Third International Pediatric Consensus Statement on the Management of Childhood Asthma. Pediatr Pulmonol 1998; 25:1-17.

8. Michael Sly. Asthma. Dalam: Behrman RE, Kliegman RM, Jenson HB, penyunting. Nelson's textbook of pediatrics. Edisi ke-15. Philadelphia: W.B. Saunders Co; 1996. h. 628-40.

9. Schuh S, Johnson DW, Callahan S, dkk. Efficacy of frequent nebulized ipatropium bromide added to frequent high-dose albuterol therapy in severe childhood asthma. J Pediatr 1995; 126:639-45.

10. Reiser J, Warner JO. Inhalation treatment for asthma. Arch Dis Child 1986; 61:88-94.

11. Bierman CV, Pearlman DS. Asthma. Dalam: Chernick V, Boat TF, penyunting. Kendig's disorders of the respiratory tract in children. Edisi ke-5. Philadelphia: W.B. Saunders Co; 1990. h. 557-601.

12. Rodrigo G, Rodrigo C, Burschtin O. A meta-analysis of the effects of ipatropium bromide in adults with acute asthma. Am J Med 1999; 107:363-70.

13. Parameswaran K, Belda J, Rowe BH. Addition of intravenous aminophylline to beta2-agonists in adults with acute asthma. Cochrane Database Syst Rev $2000 ; 4$.

14. Yung M, South M. Randomised controlled trial of aminophylline for severe acute asthma. Arch Dis Child 1998; 79:405-10.

15. Adams J, Barkin RM, Barsan WG, dkk. Management of acute asthma. Dalam: Hockberger RS, Walls RM, penyunting. Rosen's Emergency Medicine concepts and clinical practice. Edisi ke-5. St. Louis: Mosby Co; 2002. h. 947-53.

16. Fitzgerald M. Acute asthma. Clinical review. Extract from clinical evidence. BMJ 2001; 323:841-5.

17. Larsen GL, Colasurdo GN. Assessment and treatment of acute asthma in children and adolescens. Dalam: Naspitz CK, Szefler SJ, Tinkelman DG, penyunting. Textbook of pediatric asthma. United Kingdom; 2001. h.189-209. 